Yeshiva University, Cardozo School of Law

LARC @ Cardozo Law

Articles

Faculty

2004

\title{
The Antepenultimacy of the Beginning in Hegel's Science of Logic
}

David G. Carlson

Benjamin N. Cardozo School of Law, dcarlson@yu.edu

Follow this and additional works at: https://larc.cardozo.yu.edu/faculty-articles

Part of the Law Commons

\section{Recommended Citation}

David G. Carlson, The Antepenultimacy of the Beginning in Hegel's Science of Logic, 3 Cardozo Public Law, Policy, and Ethics Journal 225 (2004).

Available at: https://larc.cardozo.yu.edu/faculty-articles/21

This Article is brought to you for free and open access by the Faculty at LARC @ Cardozo Law. It has been accepted for inclusion in Articles by an authorized administrator of LARC @ Cardozo Law. For more information, please contact larc@yu.edu. 


\title{
THE ANTEPENULTIMACY OF THE BEGINNING IN HEGEL'S SCIENCE OF LOGIC
}

\author{
David Gray Carlson*
}

\section{INTRODUCTION}

Perhaps the single most perplexing problem in Hegel's Science of Logic is the status of its beginning.

Hegel famously insisted that philosophy must be self-grounding. It cannot start from givens. For Hegel, presupposition is the enemy of science. "[S]tupid-I can find no other word for it," he remarked. ${ }^{1}$ Accordingly, if Hegel's own beginning rests on unjustified presupposition, then his project is defeated at the start. This is a problem Hegel worried about and claimed to have solved. ${ }^{2}$

Hegel is usually read as excusing his presuppositional beginning by making his first step the very last step of the Logic. On this interpretation, the beginning is admittedly a contingency or a choice by the subjective will of the philosopher, ${ }^{3}$ but the first step is proven when it becomes the last step in the logic. As Hegel puts it, "The essential requirement for the science of logic is not so much that the beginning be a pure immediacy, but rather that the whole of the science be within itself a circle in which the first is also the last and the last is also the first."

* Professor of Law, Benjamin N. Cardozo School of Law.

1 G.W.F. Hegel, Hegel's Science of Logic 41-42 (A.V. Miller trans., 1969) [hereinafter SL]; G.W.F. HegEL, WISSENSCHAFT DER LoGIK 21 (1975) [hereinafter WL].

2 See Michael N. Forster, Hegel and Skepticism (1989); William Maker, Beginning, in EssaYs on Hegel's Logic 36 (George di Giovanni ed., 1990).

3 Hegel remarks, "All that is present is simply the resolve ... to consider thought as such." SL, supra note 1, at 70; 1 WL, supra note 1, at 54. See also G.W.F. HeGEL, HeGeL's LOGIC $\$ 17$ (William Wallace trans., 1975) ("To speak of a beginning of philosophy has a meaning only in relation to a person who proposes to commence the study, and not in relation to the science as science."); Clark Butler, Hegel's logic: Between Dialectic and History 1 (1996) ("the project of defining the absolute . . is certainly presupposed.").

4 SL, supra note 1 , at $71 ; 1 \mathrm{WL}$, supra note 1 , at 56. Compare with the Philosophy of Right. Philosophy forms a circle. It has an initial or immediate point-for it must begin somewhere-a point which is not demonstrated and is not a result. But the starting point of philosophy is immediately relative, for it must appear at another end-point as a result. Philosophy is a sequence which is not suspended in mid-air; it does not begin immediately, but is rounded off within itself. 
I would like to propose a refinement, however. I wish to defend the proposition that the last, ultimate step of the Science of Logic is not the first step. Rather, the first step of the logic is the antepenultimate step-the third from the last-in the Science of Logic as a whole.

This interpretation allows for an answer to a question that has bothered readers of Hegel's first chapter on pure being. There, Hegel emphasizes the identity of being and nothing. If these are identical, how can their difference be discerned? The question boils down to this: Where does difference come from? ? If one thing is clear, the result of the identity of being and nothing is becoming - a concept that depends on a difference between being and nothing. Becoming, Hegel emphasizes, is "a movement in which both [being and nothing] are distinguished ... " " Yet, in the obliterative regime of pure being, how can difference be accounted for?

If we see Hegel as beginning with the antepenultimate step in his logical system, we can provide a ready answer to the origin of difference, on which becoming depends. On my interpretation, difference is presupposed, as Hegel's critics have alleged. What is different in becoming is absolute knowing (the ultimate step) and pure immediacy (the antepenultimate step). Becoming summarizes the difference between these two-not the difference between being and nothing as such. To state this point in slightly different terms, pure being was supposed to be absolute knowing - the Understanding's propositional summary of it.

G.W.F. Hegel, Elements of the Philosophy of Right $\$ 2$ (Allen W. Wood ed., 1993) (footnote omitted).

5 John Burbidge, among others, poses this question. See, e.g., JoHN W. Burbidge, Hegel on Logic and Religion: The Reasonableness of Christlanity 14 (1992) ("But from what does this second moment of difference and disappearance arise?"). Charles Taylor, whose book did much to reverse the eclipse of Hegel's work in the twentieth century, finds this point a fatal flaw in the Logic. He writes:

[T] he derivation of Becoming here is not as solid as that of Dasein. This is the first, but not the last place in the Logic where Hegel will go beyond what is strictly established by his argument, because he sees in the relation of concepts a suggestion of his ontology .... But of course as probative arguments these passages are unconvincing. They fail, as strict conceptual proof, however persuasive they are as interpretations for those who hold Hegel's view of things on other grounds. Thus, in this case, the notion of becoming imposes itself supposedly because of the passage from Being to Nothing and back; but this is a passage which our thought is forced to when we contemplate either ... [W] cannot trade on this principle at this stage.

Charles TAYLOR, Hegel 233 (1975) (footnote omitted). Taylor's plaint is that the movement between Being and Nothing can only be "for us" and must exceed the bounds of the sparse logical development available at the end of the first chapter.

6 SL, supra note 1 , at $83 ; 1$ WL, supra note 1 , at 67. 
But it ended up being nothing at all-a failure. ${ }^{7}$ If there is a difference between being and nothing, it can only be discerned from a perspective that remembers absolute knowing and compares pure nothing as the result of the attempt to summarize absolute knowing in an immediate way.

To see how Hegel's Anfang is antepenultimate, we begin-in the style of Harold Pinter or the film noir Memento-at the end. To turn the tables on Leonard Nimoy, only by recalling the future may we comprehend the past.

\section{Hegel's Last Chapter}

Hegel's last chapter in the Science of Logic is entitled "The Absolute Idea." Generally speaking, idea is the negative unity of subject and object. Throughout the last third of the Science of Logic-the Subjective Logic-the notion or concept (Begriff) theorizes itself. It produces an objective account of its subjective self by transporting itself from subject into predicate. This occurs in the chapter entitled syllogism (Schluß), which is perhaps better translated as "inference." ${ }^{\text {In }}$ Iffect, the subject infers its own objectivity. Yet, it finds itself alienated from its self-inference and enters into a subject/object relation.

Idea is the dynamic quality that both subject and predicate share: each on its own logic has no right against the other. Each sacrifices itself on behalf of the other, pointing to the other as the source of its being. Idea is the common element of self-sacrifice-the inability of any positivized concept to maintain itself against its other.

Absolute idea arises when both the true (or thinking) and the good (or doing) give up their pretensions. What ends up being true is that Kantian philosophy is a failure. The truth is that there is no thing-initself; it is just an illusion that passes away like any other appearance. ${ }^{9}$ The good (or practical) idea, in contrast, is the obliteration of anything

7 It is possible to see Pure Being as the form of Absolute Knowing and Pure Nothing as the content of it. The job of form is to disappear in favor of a deeper truth. And nothingness is the deeper truth. Slavoj Žižek, For They Know Not What They Do: Enjoyment as a PoLITICAL FACTOR 53 (1991).

8 'It is evident that the term 'syllogism' is the worst possible translation for the German word Schluß $\beta$, which does nor signify the well-known scholastic technique for reaching a conclusion, but rather the 'issue,' the 'unification,' the 'reconciliation' of the artificial distinctions of the understanding." Eugéne Fleischmann, La SCIENCE Universelle ou la Logique DE HegEL 266 (1968) (author's translation).

9 SL, supra note 1 , at $785 ; 2 \mathrm{WL}$, supra note 1 , at $440-41$. 
that stands in the way of the subject's freedom. The good is action, and "[a]ll action presupposes a reality 'alien' to the doer ...." "10 "[A]ction," in addition, "treats the world as an empty receptacle for the actualization of its subjective purposes ...." "11 The true good, then, is the realization that the only obstacle to the subject's freedom and selfknowledge is the very falsehood that the subject manufactured in theorizing about itself. The good and the true each sacrifice themselves; this commonality shared by the true and the good is absolute idea.

Absolute idea is also called method. From the foregoing account of self-sacrifice and self-erasure, it should be clear that method is very, very negative. The method is that all affirmative propositions must obliterate themselves as inadequate to their own object. The Science of Logic, then, is thoroughly Spinozist in nature. For Spinoza, "[d]eterminateness is negation ...; this true and simple insight establishes the absolute unity of substance." 12 So it is for Hegel, with the key difference that Hegel's substance is so negative that it positivizes itself, only to dissolve its positive implication.

Like all concepts in the Science of Logic, absolute idea is put through the gauntlet of three logical steps. The first is the step of the Understanding. The Understanding makes immediate propositions. "The understanding considers all encountered beings ... to be at peace, fixed, limited, univocally defined, individual, and positive." ${ }^{13}$ To produce this stable, reliable account of reality and in order to make sense of the materials before it, the Understanding must always leave something out-reality is ultimately dynamic, but the Understanding is static.

Dialectical Reason is the critique of the Understanding. It emphasizes the omitted materials that the Understanding left out, in order to show that the Understanding's proposition is the opposite of what it ought to be. Dialectical Reason is in the business of remembering the logical sequence that the Understanding suppresses. ${ }^{14}$ Memory is the

10 Herbert Marcuse, Hegei's Ontology and the Theory of Historicity 298 (Seyla Benhabib trans., 1987).

11 Id. at 169.

$12 \mathrm{SL}$, supra note 1 , at 536; $2 \mathrm{WL}$, supra note 1, at 164 . See Letter L from Benedict de Spinoza to Jang Jettis (June 2, 1674), in 2 The Chief Works of Benedict de SPINoza 36970 (R.H.M. Elwes trans., 1951).

13 MarCuSE, supra note 10 , at 10.

14 The past is no chronological past, as logical process is not a historical process. For example, Hegel refers to essence as "timelessly past - being." SL, supra note 1, at 389;2 WL, supra note 1 , at 3 . See also BUTLER, supra note $3, \$ 112$ ("Essence we may certainly regard as past 
stuff that dialectical dreams are made of. ${ }^{15}$ Dialectical Reason is tantamount to experience, ${ }^{16}$ in that theory is shown to be inconsistent with the real world known to exist beyond the latest theory.

Yet Dialectical Reason does not just negate a positive theory. With Hegel, nothing is always something; dialectical negativity is just as positive as that which it critiques. If, according to Dialectical Reason, the Understanding has suppressed materials in order to make a positive proposition, Dialectical Reason must positivize the suppressed materials. It therefore replicates the fault laid upon the doorstep of the Understanding. ${ }^{17}$

The third step-Speculative Reason-brings together the prior, diverse steps of Understanding and Dialectical Reason, pointing out that they share a commonality or identity as well as a difference. Indeed, their commonality is their difference. In other words, each side positivizes material and so leaves aside, or expels, the negative, from which it purports to be different. It is this excluded negative (difference) that Speculative Reason exploits. Speculative Reason is constantly bringing this commonality to the fore.

The three-step process is then repeated. What Speculative Reason produces is interpreted by the Understanding. This interpretation is one-sided. Once again, something is always left out, which generates further steps in the Logic. The move from Speculative Reason to the proposition of the Understanding is always retrogressive. In Leninist terms, it is always two steps forward after one step back. "[A]dvance is a retreat into ground. . ., " as Hegel puts it. ${ }^{18}$ Nevertheless, as the Understanding interprets the material at hand, the propositions of the Understanding become more sophisticated as the Logic progresses. By the

Being, remembering however meanwhile that the past is not utterly denied, but only laid aside and thus at the same time preserved.").

15 John McCumber, The Company of Words: Hegel, Language and Systematic PHILOSOPHY 123 (1993) ("[F]or Hegel, thinking-and especially philosophical thinking-is basically a highly sophisticated way of remembering-or, as Hegel puts it, intelligence is cognitive only insofar as it is recognitive.") (footnote omitted).

16 Kenneth R. Westphal, Hegel's Epistemological Realism: A Study of the Aim and Method of Hegel's Phenomenology of Spirit 130 (1989).

17 This double nature of Dialectical Reason means that Hegel's triadic system is arguably tetrachotomous. SL, supra note 1 , at $836 ; 2 \mathrm{WL}$, supra note 1 , at 498 . In the quadratic case, Dialectical Reason is counted twice from the perspective of Speculative Reason, which sees Dialectical Reason as self-alienated. Slavoj Žıžek, The Tickıish Subject: The Absent Centre of Political Ontology 79-80 (1999).

$18 \mathrm{SL}$, supra note 1 , at $71 ; 1 \mathrm{WL}$, supra note 1 , at 56. 
time the Understanding reaches the mesne realm of Essence, all its propositions are negative and dialectical in nature. In effect, the Understanding transforms itself into Dialectical Reason. By the time the Understanding reaches the realm of Notion, it sees things speculatively. Understanding thus transforms itself into Speculative Reason. ${ }^{19}$ The Science of Logic ends when the Understanding, Dialectical Reason, and Speculative Reason converge in absolute idea. Taken together, they are method.

Because all that exists is the implosion of appearance, the major theme of the Science of Logic is that there is no mysterious "beyond" to the realm of appearances. ${ }^{20}$ It is appearances all the way down, and appearance must erase itself in favor of a beyond that turns out not even to be there. ${ }^{21}$ As Hegel remarks in the Phenomenology, "behind the socalled curtain which is supposed to conceal the inner world, there is nothing to be seen unless we go behind it ourselves, as much in order that we may see, as that there may be something behind there which can be seen." 22

Aphanisis-disappearance of the subject-is the very idea of the Science of Logic. For Hegel, this aphanisis takes on a special meaning at the advanced level of idea. To see why, it is necessary to drop back and consider the very core of Hegel's system-the true infinite, which makes its official appearance in the second chapter of the Science of Logic. The true infinite plays off the logical implication of finitude. A finite thing, by its own logic, must come to an end. Otherwise, it would not be finite. When it does end, the thing has become what it ought to benothing. Yet, for Hegel, nothing is, after all, something. If the finite thing passes away, the memory of it remains. The finite thing obtains an ideal existence when it ceases to be. Yet, in its ideal form, being is subject to recollection. The German for recollection is Errinerung,

19 For this reason, "self-contradiction comes in degrees." FORSTER, supra note 2, at 140.

20 See Jean Hyproltte, Logic and Existence 90 (Leonard Lawlor \& Amit Sen trans., 1997) ("The only secret, however, is that there is no secret."); RoberT B. Pippin, Hegel's Idealism: The Satisfactions of Self-Consciousness 206 (1989) ("[T] he major point of this section is to argue that there is literally nothing 'beyond' or 'behind' or responsible for the human experience of the world of appearances, and certainly not an Absolute Spirit."); STANLEY Rosen, G.W.F. Hegel: An InTroduction to the SCIENCE OF Wisdom 44 (1974) ("There is for Hegel nothing 'behind' that process, no hidden source or God from which Being emerges.").

21 Ermanno Bencivenga, Hegel's Dialectical logic 41 (2000) ("Reality is structure (form) all the way down;").

22 G.W.F. Hegel, Phenomenology of SpIRIt, I 165, at 103 (A.V. Miller trans., 1977). 
which can also be translated as "inwardization." True infinity is therefore the process of inwardization. Its place in the Science of Logic is the very portal from reality to ideality. In effect, ideality constitutes the memory of what was (Wesen). The true infinite becomes what it ought to be-but it also remains what it was. It is a unity of its finite self and its beyond. The true infinite therefore constantly removes itself from self-presence to a beyond-and it brings its beyond into its own presence. This double movement of cancellation and preservation is famously called sublation; ${ }^{23}$ what Slavoj Žižek calls the "chiasmic exchange of properties." ${ }^{24}$ The idea in sublation is that the finite thing invests itself into the beyond when it ceases to be, and the beyond invests itself into present thought when it ceases to be. In effect, both the finite thing and its shadowy beyond renounce their being and assign it to their other.

With the advent of absolute idea, the very idea of a beyond becomes untenable. In absolute idea, there is no longer a place to which the true infinite can withdraw. At this point, Hegel says, the distinction between form and content falls apart. Absolute idea is absolute form, "each of whose moments is within itself the totality and hence, as indifferent to the form, is the complete content of the whole." ${ }^{25}$ At the point where it is understood that there is no beyond, self-sacrificing idea can only return to itself, since there is, at this point, no other. Vanishing form is content at this stage. The point is sacrifice of self, for self.

Yet, as I have said, absolute idea must play out the three moments of the Understanding, Dialectical Reason, and Speculative Reason. Indeed, these moments literally are the Understanding, Dialectical Reason and Speculative Reason. The moments identified in the last chapter are

23 "Sublation" is a translation of Aufhebung. The English term is actually derived from chemistry. According to the Shorter Oxford Dictionary, sublation is "[a] precipitate suspended in a liquid, especially urine." Thanks to the English translators of Hegel, it also refers to the destruction and preservation of logical moments by the more progressive moment which it generates. This translative choice has been laid at the doorstep of Geoffrey Mure, an Oxford commentator from the middle of the century. ERROL E. HARRIS, AN INTERPRETATION OF THE Logic of Hegel 30 (1983); see G.R.G. Mure, The Philosophy of Hegel 35 (1965) (“'Sublated' will serve as a translation.").

24 SLAVOJ ŽIŽEK, supra note 7, at 39-41. A chiasmus is the inversion of the order of syntactical elements in the second of two juxtaposed and syntactically parallel phrases or clauses. An example: "All professors are clever men, but clever men aren't all professors;" WaLTER NASH, Rhetoric: The Wit of Persuasion 114 (1989).

$25 \mathrm{SL}$, supra note 1 , at 531; $2 \mathrm{WL}$, supra note 1 , at 158. 
method itself-each one moment implying all the others as well as itself. $^{26}$

The first step in the analysis of absolute idea is the antepenultimate step of the Science of Logic and, I contend, the true beginning for the Science of Logic. This is the step of immediacy. It represents the Understanding as such.

The second step is mediation-all the mediations there are. This is the dialectical step in which identity is paired with difference (though, covertly, Dialectical Reason actually compares two identities). The significance of mediation is that absolute idea is revealed to be an active, dialectic thinker that thinks itself. As such, it is personality, something that Hegel has declared to be missing in Spinoza's account of substance-_"a defect which has been the main cause of hostility to Spinoza's system . . . ." 27

For Spinoza, cognition is external to substance. What is finite is not derived from substance but remains alien to it. Finite concepts can be dissolved and traced back to substance, but Spinoza cannot travel in the opposite direction by deriving such concepts from substance. Accordingly, Hegel finds that Spinoza's notions of substance, "profound and correct as they are, are [mere] definitions, which are immediately assumed at the outset of the science." ${ }^{28}$ The absolute cannot be a first. It must be the result.

For Hegel, the concept thinks itself dynamically, and this means it is person-like: "The highest, most concentrated point is the pure personality which, solely through the absolute dialectic which is its nature, no less embraces and holds everything within itself, because it makes itself the supremely free-the simplicity which is the first immediacy and Universality." 29 Personality implies life, but also the cognition of being alive. Life is immediate idea- "impenetrable atomic subjectivity." ${ }^{30}$ Life ends up standing for self-sacrifice. There can only be life in general if individual lives terminate in death. Cognition - the second, dialectical portion of idea ${ }^{31}$-is mediated idea. It cognizes itself as Life and so, too, it

26 As John Burbidge puts it, "method identifies its own internal conditions, making no reference to anything external." John W. Burbidge, ON Hegel's Logic: Fragments of A COMMENTARY 217 (1981).

27 SL, supra note 1 , at 537; $2 \mathrm{WL}$, supra note 1 , at 164 .

$28 \mathrm{SL}$, supra note 1 , at 537; $2 \mathrm{WL}$, supra note 1 , at 164.

29 SL, supra note 1 , at $841 ; 2$ WL, supra note 1 , at 502.

$30 \mathrm{SL}$, supra note 1, at 824; $2 \mathrm{WL}$, supra note 1, at 484.

$31 \mathrm{SL}$, supra note 1, at 775-824; $2 \mathrm{WL}$, supra note 1, at $429-83$. 
sacrifices itself. This implies that absolute knowing-the ultimate step-is, as negation of the negation, the sacrifice of self-sacrifice. On its own logic, Absolute knowing shows what it is when it stops sacrificing itself and produces some positivized account of itself, an account in which Geist aspires not to sacrifice itself. For this reason, in the very last step of the Logic, Absolute idea returns to immediacy as its final act of self-manifestation. Absolute knowing is therefore the unity of doing (or thinking) and being. It is divine creation-what Kant called "intellectual intuition." 32 What it thinks truly is.

Absolute knowing is the ultimate step in the Science of Logic. Significantly, it is also the very last step in the Phenomenology. This congruence is significant because, in the Science of Logic, Hegel expressly describes the Phenomenology as presupposed by the Science of Logic. ${ }^{33}$ Absolute knowing stands for the realization that human consciousness is not any basis for scientific philosophizing. ${ }^{34}$ In effect, absolute knowledge "ceases itself to be knowledge." ${ }^{35}$ It is also all the knowledge there is-that there is no knowledge. There is only the appearance of knowledge.

32 Immanuel Kant, Critique of Pure Reason 163-64 (J.M.D. Meiklejohn trans. 1990). Charles Taylor says that:

Hegel reproaches Kant [is] for ... not having cleaved to the notion of an intellectual intuition, which he himself invented. This would be an understanding which unlike ours did not have to depend on external reception, on being affected from outside, for its contents, but created them with its thought. This archetypical intellect Kant attributed to God; it was quite beyond us. But God's intellect is ultimately revealed to us for Hegel, it only lives in our thought. Hence we can participate in an intellectual intuition. God's thought is ours.

TAYLOR, supra note 5 , at 301 .

33 SL, supra note 1, at 49; $1 \mathrm{WL}$, supra note 1 , at 30.

34 Professor Winfield complains that Marx, Kierkegaard et al. miss the punch line of the Phenomenology.

Instead of properly regarding absolute knowing as the collapse of the posited structure of consciousness, they have commonly interpreted it as a determinate cognition that somehow unites subject and object such that its knowing both comprehends and constitutes things as they are in themselves. . . . Accordingly, Hegel becomes labeled an objective idealist, a philosopher of subject-object identity, a thinker of self-revealing totality, and the consummator of metaphysics for whom thought and being are one.

Richard Dien Winfield, Overcoming Foundations: Studies in Systematic PhilosoPHY 26-27 (1989) (footnote omitted).

$35 \mathrm{SL}$, supra note 1 , at $69 ; 1 \mathrm{WL}$, supra note 1 , at 54. 


\section{Hegel's First Chapter}

The beginning of the Science of Logic, I contend, is the antepenultimate step from Hegel's last chapter. The beginning is simply the immediate version of absolute knowing. It is what the ultimate step of absolute knowing, on its own logic, must produce. For this reason, the first step is not, as usually supposed, the ultimate speculative step or the penultimate dialectic step, but the antepenultimate step-the Understanding, as such.

The following diagram shows the structure of the beginning in the Science of Logic. In this diagram, the left side of the page is to be identified with positivity. The right side of the page leans to negativity. The middle of the page is positivity and negativity thought together. So conceived, absolute knowledge can be portrayed as follows:

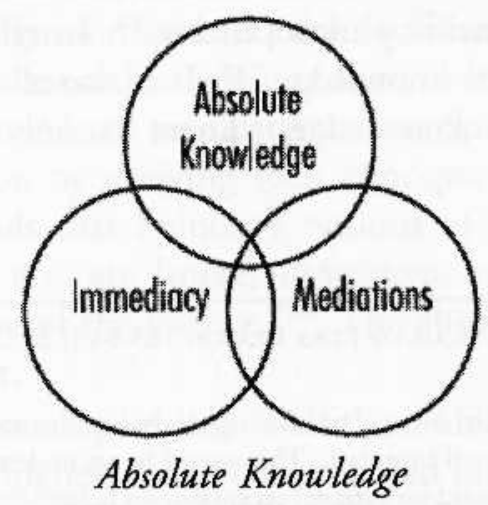

Hegel's beginning, in contrast, is an immediate proposition about absolute knowing:

In this drawing, pure being is shown to be a one-sided view of all the knowledge there is. In effect, the concept, if it is to know itself, must make a proposition about itself. It must say affirmatively what it $i s^{36}$ And, given that absolute knowing is the end of the logic, it must recall, or remember what it is; being complete and total, whatever it once was is now in its (timeless, logical) past.

36 Andrew Haas correctly suggests that, not pure being, but the decision of the Understanding to abstract pure being from absolute knowing constitutes the true first step of the Logic. Andrew HaAs, Hegel and the Problem of Multiplicity 91 (2000). Similarly, Walter Kaufmann notes that the Logic does not really start from pure being. Rather, the Logic starts with the privileging of the immediate over what is mediated. Walter KaufmanN, Hegel: A REINTERPRETATION 190 (1978). 


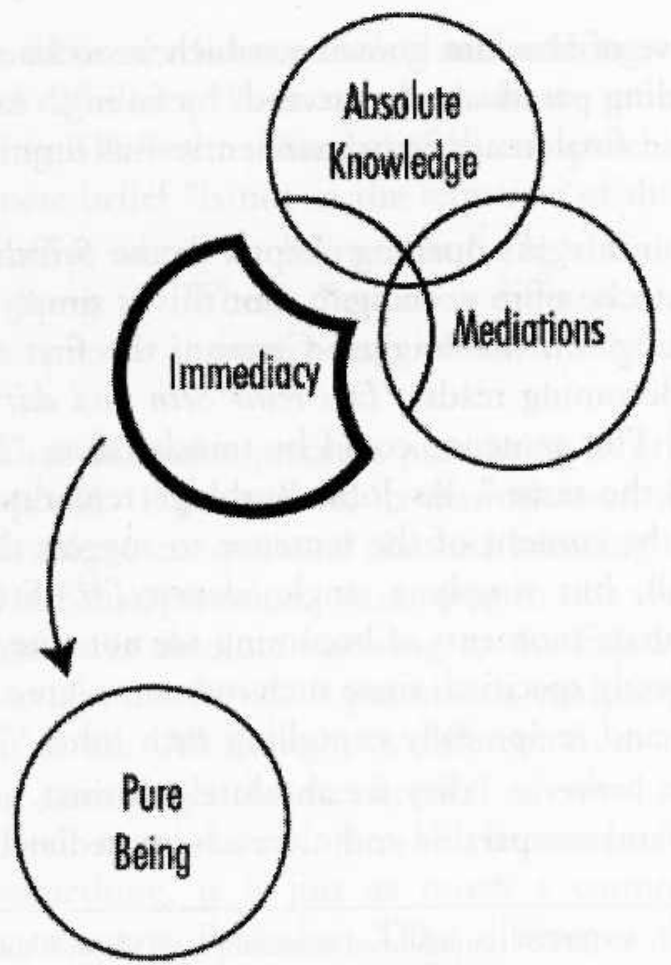

Hegel's Beginning

But this first thought of itself is a failure. It fails even to be a thought, for, "there is nothing, nothing in heaven or in nature or mind or anywhere else which does not equally contain both immediacy and mediation, so that these two determinations reveal themselves to be unseparated and inseparable and the opposition between them to be a nullity." ${ }^{37}$ In this recollection, the motor of the logic-contradictioncannot get started..$^{38}$ Absolute idea perpetually turns the ignition key of Understanding and gets no result. In an important, paradoxical way, Hegel's beginning is a failure, as many scholars have suspected. But Hegel makes his failure his success. The failure to have a thought at all is the beginning of the Science of Logic. ${ }^{39}$ And curiously, non-thought is

$37 \mathrm{SL}$, supra note 1 , at $68 ; 1 \mathrm{WL}$, supra note 1 , at 52 . For Adorno, this is the equivalent of saying there is "nothing ... that does not contain, merely by being defined as something that exists, the reflection of its mere existence, a spiritual moment." THEODOR W. AdORNO, Hegel: Three Studies 57 (1993).

38 TAYLOR, supra note 5, at 243.

39 This justifies Clark Burler's insight: "Hegel's great originality was to have claimed, contrary to Aristotle, that an inquiry starting from a false assumption could be a science, and indeed was alone qualified to be science." Clark Butler, The Dialectical Method Today: An Essay in 
highly descriptive of absolute knowing, which is no knowledge at all. ${ }^{40}$ The Understanding paradoxically succeeds by failing. And in its failure it anticipates the final result very presciently-all immediate propositions must fail.

Famously, in Hegel's opening chapter in the Science of Logic, pure being is shown to be pure nothing. ${ }^{41}$ But this is simply the identity of being and nothing. In the original German, the first sentence of the subsection on Becoming reads: "Das reine Sein und das reine Nichts ist also dasselbe." 42 This sentence could be translated as: "Pure being and pure nothing is the same." As John Burbidge remarks: "The singular verb reinforces the content of the sentence to suggest that there is not movement at all, but simply a single identity." ${ }^{43}$ Strictly speaking, " $[t]$ he indeterminate moments of becoming are not true moments; they cannot be concretely specified, since such moments 'are always changing into each other and reciprocally cancelling each other." ${ }^{44}$

Hegel adds, however, "they are absolutely distinct, and yet ... they are unseparated and inseparable and ... each immediately vanishes in its

Analytical Hegelianism 49 (2003) (unpublished manuscript, on file with the CARDOzo PuB. L. Pol'y. \& Ethics J.). See also Slavoj Žižze, The Puppet and the Dwarf: The Perverse CORE OF CHRISTIANITY 83 (2003) ("[O]ne has to begin by making the 'wrong' choice ... the true speculative meaning emerges only through repeated reading, as the aftereffect (or byproduct) of the first, 'wrong' reading."); Angelica Nuzzo, The End of Hegel's Logic: Absolute Idea as Absolute Method, 3 Cardozo PuB. L. Pol'y. \& ETHICS J. 203 (2005) ("For Hegel progress is made by staying where one is not by looking away aiming at something else.").

40 Professor Winfield complains that Marx, Kierkegaard et al. miss the punchline of the Phenomenology. See supra text accompanying note 34.

41 Marcuse is partly right in asserting, "In the foregoing analysis of the concept of being, being did not 'turn into' nothing, but both were revealed as identical .... "HERBERT MARCUSE, Reason and Revolution: Hegel and the Rise of Social Theory 130 (1999). But Marcuse errs in deducing from this fact alone that "every determinate being contains the being as well as the nothing." Id. In order for this result to follow, difference is required. But difference cannot be found in the non-dialectic relation of pure being and pure nothing. Furthermore, Marcuse errs in denying that transition is proper to the realm of being. Id. at 131 ("Moreover, it is not quite correct to say that one category 'passes into' another. The dialectical analysis rather reveals one category as another, so that the other represents its unfolded content ...."). Such a view denies difference. Transition is the very hallmark of the realm of being. Hegel in fact defines becoming as "transition into an other." SL, supra note 1 , at $601 ; 1$ WL, supra note 1, at 240.

421 WL, supra note 1 , at 67.

43 Burbidge, supra note 5, at 14. Andrew Haas reads Hegel as making a deliberate grammatical mistake to emphasize the inability of ordinary grammar to account for speculative philosophy, which accounts for simultaneous immediacy and mediation. HAAs, supra note 36 , at 97.

44 PIPPIN, supra note 20 , at 189. 
opposite." 45 Any difference between being and nothing is "a merely fancied or imagined difference." 46 In other words, we mortals believe that being and nothing is different. But belief has no purchase in logic. As Hegel puts it, mere belief "is not in the sequence of this exposition." 47

It cannot suffice merely to believe that being and nothing is different. We must prove it. Where then does difference come from? It specifically is not present in pure being, which is only identical to pure nothing.

I contend that difference precedes pure being in origin. That is to say, it is presupposed. Furthermore, its identification depends upon a viewpoint that is able to comprehend absolute knowing standing against its initial, failed self-interpretation. According to this viewpoint, Speculative Reason compares absolute knowing to the failed attempt of the Understanding to account for it. It perceives a vanishing of all thought into no thought at all. All thought is different from no thought. In short, becoming constitutes the recollection of what once was, compared to what is not now- a ceasing-to-be. But since, for Hegel, nothing is always something, it is just as much a coming-to-be-a becoming. Again to quote Burbidge, "The difference that 'reality' introduces is not the result of a simple transition, but has been posited by reflection when it added to the immediate content ... . its remembered parentage. The move came from outside the immediate concept." ${ }^{8}$

This implies that there is no proper beginning for Hegel. He is, as Jean-Luc Nancy observes, "the first philosopher for whom there is, explicitly, neither beginning nor end."49 An articulation of this principle appears in the following passage:

Simple immediacy is itself an expression of reflection and contains a reference to its distinction from what is mediated. This simple immediacy, therefore, in its true expression is pure being. . . . Here the be-

45 SL, supra note 1 , at 83; $1 \mathrm{WL}$, supra note 1 , at 67.

46 SL, supra note 1 , at 92; 1 WL, supra note 1 , at 77.

47 "[D]as nicht in diese Reihe der Darstellung gehört." 1 WL supra note 1, at 78. A.V. Miller's translation puts it more dryly: "Opinion, however, is a form of subjectivity which is not proper to an exposition of this kind." SL, supra note 1, at 92; 1 WL, supra note 1, at 77.

48 BURBIDGE, supra note 5, at 22.

49 Jean-Luc Nancy, Hegel: The Restlessness of the Negative 9 (Jason Smith \& Steven Miller eds. 1997) (footnote omitted); see also AdoRNo, supra note 37, at 12 ("Correctly understood, the choice of a starting point, of what comes first, is a matter of indifference in Hegel's philosophy; his philosophy does not recognize a first something of this kind as a fixed principle ....".). 
ginning is made with being which is represented as having come to be through mediation, a mediation which is also a sublating of itself; and there is presupposed pure knowing as the outcome of finite knowing, of consciousness. But if no presupposition is to be made and the beginning itself is taken immediately, then its only determination is that it is to be the beginning of logic, of thought as such. All that is present is simply the resolve, which can also be regarded as arbitrary, that we propose to consider thought as such. ${ }^{50}$

In this passage, Hegel admits that the indeterminacy of pure being contains a reference to determinacy. Pure being cannot properly disentangle itself from its history. Pure being is different from its history. Yet, as pure being, it is immediacy and only immediacy, and, as such, it must suppress its history. But without its history, it reduces to mere resolve to begin, and, as such, it looks arbitrary. Why should we begin? At the beginning this is by no means clear. ${ }^{51}$ But by the end, we know that idea requires its own manifestation. It must begin.

What pure being is different from is not pure nothing but pure knowing-Logic's ultimate step. By way of evidence, in the subsection entitled "Nothing," Hegel says:

To intuit or think nothing has, therefore, a meaning; both are distinguished and thus nothing is (exists) in our intuiting or thinking; or rather it is empty intuition and thought itself, and the same empty intuition or thought as pure being. Nothing is, therefore, the same determination, or rather absence of determination, and thus altogether the same as, pure being. ${ }^{52}$

$50 \mathrm{SL}$, supra note 1 , at $69-70 ; 1 \mathrm{WL}$, supra note 1 , at 54.

51 In Professor Winfield's account, the matter must end here. Rather than viewing the true commencement of the Logic as the one-sided proposition of the Understanding, Winfield thinks that determinacy arises for no reason:

One could thus say that the proper answer to the question "Why is there determinacy?" is that there is and can be no reason, for any attempt to assign one presupposes determinacy by treating indeterminacy as if it were a definite determiner. All that can be offered in answer is an account of how indeterminacy gives rise to something else. What is clear from the start is that what follows from indeterminacy must do so immediately, which is to say, without reason, and without being determined by anything.

WINFIELD, supra note 34, at 50. But if this is so, there can be no account for how Speculative Reason, in arriving at "becoming," finds the tools to differentiate stasis from movement.

52 SL, supra note 1, at 82; 1 WL, supra note 1 , at 67. 
This passage expressly refers to difference, and what is different is thinking and thought. Thinking stands for absolute knowing, which, we know from Hegel's last chapter, has the active principle-personality. The thought, or, more precisely, the failed thought of being/nothing, is passive/identical. The thought contains within itself no difference. Difference is, however, already on the scene in becoming. What is different is (a) the entire Science of Logic as embodied in absolute knowing and (b) the failed, indeterminate thought of being/ nothing.

Admittedly, Hegel emphasizes a movement between pure being and pure nothing. In a passage that few have failed to miss as highly important, Hegel writes:

What is the truth is neither being nor nothing, but that being-does not pass over but has passed over-into nothing .... But it is equally true that they are not undistinguished from each other ... they are absolutely distinct, and yet that they are unseparated and inseparable and that each immediately vanishes in its opposite. Their truth is, therefore, this movement of the immediate vanishing of the one in the other: becoming, a movement in which both are distinguished, but by a difference which has equally immediately resolved itself. ${ }^{53}$

The past tense of pure being and pure nothing is important. Pure being and nothing is never before us as a thought-because it is unthinkable. It is a failed thought. It is retroactively theorized only. And in support of this interpretation, it may be noted that Hegel states that pure being and pure nothing "have no separate subsistence of their own but are only in becoming .... " 54 For this reason, becoming is not, strictly speaking, a transition. With transition, Hegel writes, "one tends to think of the two terms, from one of which transition is made to the other, as at rest, apart from each other, the transition taking place between them." 55 Since pure being and nothing is less than thought, the two terms cannot be brought together in the relation Hegel calls transition. ${ }^{56}$

$53 \mathrm{SL}$, supra note 1 , at $82-83 ; 1 \mathrm{WL}$, supra note 1 , at 67.

$54 \mathrm{SL}$, supra note 1, at 93; $1 \mathrm{WL}$, supra note 1 , at 79.

55 SL, supra note 1, at 93; 1 WL, supra note 1 , at 79.

56 See ROSEN, supra note 20, at 111 ('There is, then, never a transition 'taking place' from Being to Nothing and thence to Becoming; instead, such a transition has already taken place ...."). 
Hegel refers to movement between being and nothing. Strictly speaking, this movement has to be understood not as the movement between being and nothing, but as the movement from absolute knowing (or active thinking) to being/nothing, its first failed proposition about itself. ${ }^{57}$ This is no move forward but a move back from the ultimate step of absolute knowing to the antepenultimate step of immediacy. In describing what it is, absolute knowing must recall its beginning. Recollection of the antepenultimate step then becomes the first step of the Science of Logic.

Further evidence of Hegel's intent can be brought to bear. At the opening of his essay, "With what must the Science Begin?", Hegel states that the beginning can be either mediated or unmediated-but either way of beginning is refuted in advance. ${ }^{58}$ In other words, the beginning must fail. If it did not, then there would be no possibility of progress beyond the beginning. "Hence the advance is not a kind of superfluity; this it would be if that with which the beginning is made were in truth already the absolute ... ". 59 In short, it is the very nature of a beginning that it must fail; otherwise it would be result-not beginning. ${ }^{60}$

Compared to its origin in absolute knowing, the beginning of pure being is "concentrated into this unity [that] has sublated all reference to an other and to mediation...." be-abstract and unmediated, because mediation points to some other, prior step that is actually the true beginning. And yet this reference to other is precisely what pure being implies. To repeat what Hegel has said, "Simple immediacy is itself an expression of reflection and contains a reference to its distinction from what is mediated." in spite of itself, pure being refers to something other than itself, and so

57 This meaning underwrites Hegel's remark that being and nothing "sink from their initially imagined self-subsistence to the status of moments, which are still distinct but at the same time are sublated." SL, supra note 1 , at $105 ; 1 \mathrm{WL}$, supra note 1 , at 92 . Absolute knowing is self-subsistent, and pure being is the Understanding's proposition about absolute knowing. Only an overarching perspective that recalls absolute knowing and its difference from being/ nothing can see in being/nothing a ceasing-to-be and a becoming.

$58 \mathrm{SL}$, supra note 1 , at $67 ; 1 \mathrm{WL}$, supra note 1 , at 51 .

$59 \mathrm{SL}$, supra note 1 , at $829 ; 2 \mathrm{WL}$, supra note 1 , at 489.

60 As Kathleen Dow Magnus puts it: "Implicit to the meaning of self-determination, however, is the experience of not having been what one determines oneself to be. Genuine selfdetermination requires that one was not 'always already' self-determining. For Hegel, there is no such thing as simply being self-determining." KatHleEN DOw MAGNUS, HeGEl and THE Symbolic Mediation of SPIRIt 235 (2001).

$61 \mathrm{SL}$, supra note 1 , at $69 ; 1 \mathrm{WL}$, supra note 1 , at 54 .

62 SL, supra note 1 , at 69; 1 WL, supra note 1 , at 54. 
as a beginning it is a failure. This requires an overarching perspective that can discern the difference between absolute knowing, on the one hand, and being and nothing, on the other.

\section{Becoming as the True Beginning}

Pure being is merely identical to, not different from, pure nothing. Accordingly, pure being and pure nothing are not even moments. Rather, they are retrospective reflections on what must have been. As Marcuse puts it, "Hegel says explicitly that not being but having been (Gewordensein) is to be grasped as a becoming." ${ }^{33}$ Here, Marcuse refers to the "has passed over" remark from the passage quoted above. ${ }^{64}$

Some have therefore suggested that becoming is the first true thought in the logic. Gadamer is of this view, and he quotes the Lectures in the History of Philosophy to back it up: "One has acquired great insight when one realizes that being and not-being are abstractions without truth and that the first truth is Becoming alone." 65

Why does Gadamer claim that Becoming is the true beginning? According to Gadamer, pure being and pure nothing are simply presuppositions for Becoming. They are not things in themselves. We first think of Becoming - we cannot think the unthinkable pure being or pure nothing. Then we reason that, if change or transition exists, it must have changed from something. Only in becoming is difference manifested. Yet, Gadamer says, the converse is not convincing. Why should we think of Becoming when we light upon pure being or pure nothing?

Yet, in so observing, Gadamer forgets that being and nothing are unthinkable. As we cannot think them, there is little use in observing that they do not imply becoming. What becoming/ceasing-to-be represents is not the difference between being and nothing but rather the difference between thinker and (failed) thought. Gadamer is right that there can be no derivation of becoming from being and nothing. Being and nothing represents a recollection by absolute knowing of what it

63 Marcuse, supra note 10 , at 15.

64 SL, supra note 1 , at 83; 1 WL, supra note 1 , at 67.

65 Hans-Georg Gadamer, Hegel's Dialectic: Five Hermeneutical Studies 91 (P. Christopher Smith trans., 1976) (citing XIII G.W.F. Hegel, WERKE 306 (1832)). See 1 Hegel's Lectures on the History of Philosophy 283 (E.S. Haldane trans., 1892) ("The recognition of the fact that Being and non-being are abstractions devoid of truth, that the first truth is to be found in Becoming, forms a great advance."). 
once must have been. What becoming represents is all the Science of Logic ceasing to be in the Understanding.

Although the logical method depends on the sequence of Understanding, Dialectical Reason, and Speculative Reason, Gadamer rightly observes that the transition from being/nothing to Becoming is a special case. There is nothing dialectical about pure nothing. On its own, pure being and nothing is so little different that it can generate no synthesis. Any difference assigned to it is merely a matter of subjective belief, not Logic. For this reason, Gadamer emphasizes that pure nothing "bursts forth immediately" from pure being. "Clearly, the expression, "bursts forth,' is one carefully chosen to exclude any idea of mediation and transition." "66

Yet, Gadamer seems to be criticizing Hegel's claim that pure being is the beginning. The modulation between pure being and pure nothing, which Hegel emphasizes, is, for Gadamer, an "untenable way of putting the matter . . . " "67 I agree that it is untenable, but I do not read Hegel as making this point. For Hegel, the modulation between being and nothing is not what precedes becoming. What precedes becoming is thinking which fails to form a thought of its own being. Instead of contemplating its own being, absolute knowing finds before it nothing at all. In thought it has ceased to be. The beginning, Hegel says, "is to be made in the element of thought that is free and for itself, in pure knowing."68 "Now starting from this determination of pure

66 GADAMER, supra note 66, at 87. In the Miller translation, the sentence Gadamer is referring to is: "In the pure reflection of the beginning as it is made in this logic with being as such, the transition is still concealed; because being is posited only as immediate, therefore nothing emerges in it only immediately." SL, supra note 1, at 99; 1 WL, supra note 1, at 85 . Gadamer's translation renders "emerges in it only immediately" into "bursts forth immediately." Id. at 87. See 1 WL, supra note 1, at 85 ("bricht das Nichts an ihm nur unmittelbar hervor."). A later remark by Hegel makes the point expressly:

[T] he transition of being and nothing into each other, . . . it is to be understood as it is without any further elaboration of the transition by reflection. It is immediate and quite abstract because the transient moments are themselves abstract, that is, because the determinateness of either moment by means of which they passed over into each other is not yet posited in the other; nothing is not yet posited in being, although it is true that being is essentially nothing, and vice versa. It is therefore inadmissible to employ more developed forms of mediation here and to hold being and nothing in any kind of relationship-the transition is not yet a relation. [No ground or relation can be allowed.] The kind of connexion cannot be further determined without the connected sides being further determined at the same time.

SL, supra note 1 , at $103 ; 1 \mathrm{WL}$, supra note 1 , at $89-90$.

67 GADAMER, supra note 65 , at 89 .

$68 \mathrm{SL}$, supra note 1 , at $68 ; 1 \mathrm{WL}$, supra note 1 , at 53. 
knowledge, all that is needed to ensure that the beginning remains immanent in its scientific development is to consider . . . simply to take up, what is there before us." 69 These sentences show that becoming is not the beginning - even if it is the first determinate thought in the Science of Logic. Rather, the collapse of absolute knowing is the beginning.

Nevertheless, Gadamer justly attacks the very question, How does becoming emerge from pure being? It does not emerge at all. Becoming is absolute knowing itself, as it stands back from its own failed proposition, learning from its failure that when it tries to think an immediate thought, it ceases to be in that thought and is alienated from its product. $^{70}$

For this reason, the transition from pure nothing and pure being to becoming should be viewed as a non-transition, since transition implies a difference between origin and result. Hegel was aware of this when he referred to the fact that being "does not pass over but has passed overinto nothing ...." ${ }^{71}$ Pure being and pure nothing are simply what becoming implies.

Becoming, for Gadamer, is the first successful thought and is therefore the true beginning, because the thought of pure being is a failure. ${ }^{72}$ But this interpretation wrongly presupposes that the beginning must be a success. I think Hegel intends for the beginning to be a failure, containing a reference to some prior origin in spite of itself.

\section{CONCLUSION}

Hegel aims for a presupposition-free philosophy. Logic is a circle, as every Hegelian knows. Yet movement in Logic is a "lumpy, bumpy

$69 \mathrm{SL}$, supra note 1 , at 69; 1 WL, supra note 1 , at 54.

70 As Hyppolite puts it, "[t]o know oneself is to contradict oneself, since this is simultaneously to alienate oneself, to direct oneself towards the Other and to be reflected into it, or more exactly, to be reflected into oneself in the Other." Hyppolite, supra note 20, at 75.

71 SL, supra note 1, at 82-83; $1 \mathrm{WL}$, supra note 1 , at 67.

72 Adorno agrees. He writes that, when Hegel deals with Becoming

$[\mathrm{H}] \mathrm{e}$ waits until being and Nothingness have been equated as wholly empry and indefinite before he pays attention to the difference indicated by the fact that the two concepts' literal linguistic meanings are absolutely contrary. ... [I]t is not until their synthesis identifies them with each other that the moments will be nonidentical. This is where the claim of their identity obtains that restlessness, that inward shudder, which Hegel calls Becoming.

Theodor W. Adorno, Negative Dialectics 157 (E.B. Ashton trans., 2000). 
triangular wheel." ${ }^{\text {33 }}$ Logic progresses by dropping back and hazarding one-sided propositions doomed to fail in advance. This is just as true of Hegel's beginning. Pure being, which is pure nothing, is just such a retrogression. In the methodical progress that Hegel describes, the beginning is a retrogression to the antepenultimate step-the appearance of the Understanding, the faculty of immediacy. Hegel's beginning is a failure, and that is why it succeeds.

73 John Burbidge, Where is the Place of Understanding?, in ESSAYS ON HEGEL's LOGIC 180 (George di Giovanni ed., 1990). 